\title{
Mentor's Statement
}

National Cancer Institute

\section{Source}

National Cancer Institute. Mentor's Statement. NCI Thesaurus. Code C19489.

A description of the kind and extent of supervision, guidance and advice that the mentor intends to contribute to the trainee during the proposed award period. 